\title{
STUDIES ON DEVELOPMENT AND STORAGE OF BOTTLED PENIPOL
}

\author{
K.D.P.P. Gunathilake and C. Jayasekera \\ Coconut Research Institute,Lunuwila, Sri Lanka
}

\begin{abstract}
Penipol or "candied coconut" made from coconut and sugar, is used as a sweet filler in traditional food preparations in Sri Lanka. A ready-to-serve, preserved Penipol is likely to have a good demand among both local urban consumers and Sri Lankan communities overseas. The main objective of this study was to develop a simple technique to produce a bottled Penipol with an extended shelf life, in order to exploit this perceived demand.
\end{abstract}

In a preliminary trial it was established that a Penipol product, acceptable to consumer in terms of colour, taste and texture, was derived from a blend of coconut and sugar in the ratio of 2.5:2.0. This blend with added Vitamin $E$ (80 ppm), salt, spices was used to prepare Penipol for the studies on Pasteurization and storage, and the physico-chemical analyses. This product contained $3.58 \%$ protein, $20.78 \%$ fat, $7.00 \%$ fiber and $0.83 \%$ minerals and its water activity, $\mathrm{pH}$ and total soluble solids were $0.8,5.5$ and $65^{\circ}$, respectively.

Penipol, bottled in jars, was pasteurized in boiling water. Five heat treatments (boiled for 15, 30, 45, 60 minutes and no heat treatment) were tested. Microbial analysis of the Penipol, stored for one month, showed that pasteurizing for $\mathbf{3 0}$ minutes was adequate to prevent microbial growth and achieve commercial sterility.

The keeping quality of bottled Penipol, pasteurized for $30 \mathrm{~min}$., was studied by conducting sensory evaluations, at 3-monthly intervals, over a 12 months storage period. Statistical analysis showed that there is no significant difference in sensory properties between freshly prepared and preserved Penipol throughout the studied period. The free fatty acid levels remained unchanged at $0.05+/-0.02$ (as \% of lauric acid). Results indicated that Penipol can be preserved for at least 12 months by applying a simple bottling technique with $30 \mathrm{~min}$. pasteurization in boiling water.

\section{INTRODUCTION}

"Penipol" (Candied coconut) is a coconut based product which consists of grated coconut, caramelized sugar (or treacle), salt and a few selected spices. It is used as an ingredient or "sweet filler" in the preparation of sweet 
foods like "Laveria", "Imbul kiribath", "Halapa", pancake etc. However, Penipol cannot be kept for more than two days without refrigeration because it develops rancidity and is subject to microbial spoilage. Rancidity development in food is mainly due to the lipids undergoing complex chemical changes and reacting with other food constituents during processing and storage. Addition of antioxidants such as Tocopherol during processing delays or suppresses rancidity development. Tocopherol exerts its maximum effectiveness at relatively low concentrations of approximately 80ppm (Bockish, 1998).

The shelf stability of food products are prolonged by the application of bottling or canning technology where food and its container are rendered commercially sterile by application of heat alone or in combination with $\mathrm{pH}$ adjustment or water activity (Cruess, 1958). There is an increasing demand for convenience foods to save time devoted to preparing food. Ready-toserve, bottled Penipol is a product which has a potential in the local market and may also have export potential especially for expatriate Sri Lankan communities in Europe and Middle East. It is in this context that the present study set out to develop "bottled Penipol" with an extended shelf life.

\section{MATERIALS AND METHOD}

\section{Ratio of coconut to sugar in Penipol:}

Different quantities of good quality scraped coconut were blended with a standard hot caramelized sugar solution (2 kg sugar in $800 \mathrm{ml}$ water-Total Soluble Solids (TSS) $85^{\circ}$ ) to determine the best proportion of these ingredients. Ten samples from each blend were observed for taste, colour and texture. Based on these observations, the best formulation was selected for preparing Penipol used in this studies.

\section{Preparation of Penipol :}

\section{Penipol was prepared as follows}

1. Sugar $(3.6 \mathrm{~kg})$ was heated in a cooking pan with 1.44 liter water until the total soluble solid level reached to $85^{\circ}$.

2. Vitamin $E(400 \mathrm{mg})$ and salt $(15 \mathrm{~g})$ were dissolved in the caramelized sugar solution prior to mixing of coconut.

3. Scraped coconut $(4.5 \mathrm{~kg})$ was added to this sugar solution and was mixed. 
4. This mixture was heated further period of $10 \mathrm{~min}$. with continue mixing. In the final stage of cooking, $5 \mathrm{~g}$ of crushed mixture of cardomom and pepper (2:1) was added and mixed thoroughly.

\section{Studies on bottling technology:}

\section{i. Pasteurization studies:}

Freshly prepared Penipol was filled into pre-sterilized jars, while it was still hot, leaving a headspace of $1 \mathrm{~cm}$. The unsealed jars were placed in a boiling water bath for $10 \mathrm{~min}$. The jars were then sealed with caps, manually. The sealed Penipol jars were subjected to the following heat treatments. Three jars were used per treatment.

T1- Control-No heat treatment

T2- $15 \mathrm{~min}$. in boiling water

T3- $30 \mathrm{~min}$. in boiling water

T4- $45 \mathrm{~min}$. in boiling water

T5- $60 \mathrm{~min}$. in boiling water

After a storage period of one month, microbial analyses were done by serial dilution of the pour plate method described in AOAC (1995). Microbial counts were used to determine the optimum heat treatment to achieve commercial sterility.

\section{Storage studies:}

A batch of bottled Penipol pasteurized for $30 \mathrm{~min}$. in a boiling water bath was prepared for the shelf life study. The bottles were stored for 12 months at ambient condition $\left(30^{\circ}+1-2 \mathrm{C}\right)$ and samples drawn at three monthly intervals were evaluated by 30 untrained judges. At each sampling Laveria with freshly prepared Penipol and bottled Penipol as the filler, were presented to the panel for grading their colour, flavour and overall acceptability. A five point Hedonic scale with 5 for excellent and 1 for highly disliked was employed for scoring. Free fatty acids level of the samples was also determined.

\section{Measurement of physico-chemical properties:}

Total soluble solid levels and $\mathrm{pH}$ of Penipol were measured by using a refractometer (ATAGO NIE) and a pH meter (Cyb er Scan 510), respectively. Water activity of Penipol was determined by measuring the Equilibrium Relative Humidity (ERH) using an electric humidity sensor (CHS-UPS TC 2, TDK). 


\section{Chemical analysis:}

Moisture, protein, fats, fiber and total ash contents were determined by standard AOAC method (1990) and the carbohydrate \% was determined by difference. The free fatty acids content of the stored samples was determined employing the method prescribed by Pearson (1973)

\section{RESULTS AND DISCUSSION}

The results of evaluation of Penipol formulations with various ratios of sugar to coconut are shown in Table 1. All the formulations tested gave products with a good taste. Coconut to caramel sugar $\left(85^{\circ}\right)$ at $1: 1$ ratio gave a product with a juicy texture because of an excess of sugar. Coconut to sugar at ratios of 3:2 and 3.5:2 gave products with a light colour indicating insufficient caramel sugar. Coconut to caramel at the ratio of 2.5 to 2.0 was the only formulation that gave an acceptable product with good taste, texture and colour.

Table 1: Sensory evaluation of Penipol formulations

\begin{tabular}{llll}
\hline Formulation & Blends & Observations & $\begin{array}{l}\text { Consumer } \\
\text { acceptability } \\
\text { of the product }\end{array}$ \\
\hline 1 & $\begin{array}{l}\text { Coconut } 2.0 \mathrm{~kg} \\
\text { Caramel sugar } 2.0 \mathrm{~kg}\end{array}$ & $\begin{array}{l}\text { Taste-good } \\
\text { Colour-good } \\
\text { Texture-juicy }\end{array}$ & Unacceptable \\
2 & $\begin{array}{l}\text { Coconut } 2.5 \mathrm{~kg} \\
\text { Caramel sugar } 2.0 \mathrm{~kg}\end{array}$ & $\begin{array}{l}\text { Taste-good } \\
\text { Colour-good } \\
\text { Texture-good }\end{array}$ & Acceptable \\
3 & $\begin{array}{l}\text { Coconut } 3.0 \mathrm{~kg} \\
\text { Caramel sugar } 2.0 \mathrm{~kg}\end{array}$ & $\begin{array}{l}\text { Taste-good } \\
\text { Colour-light } \\
\text { Texture-good }\end{array}$ & Unacceptable \\
\hline & $\begin{array}{l}\text { Coconut } 3.5 \mathrm{~kg} \\
\text { Caramel sugar } 2.0 \mathrm{~kg}\end{array}$ & $\begin{array}{l}\text { Taste-good } \\
\text { Colour-too light } \\
\text { Texture-good }\end{array}$ & Unacceptable \\
\hline
\end{tabular}

\section{Chemical analysis:}

The composition of Penipol (coconut 2.5:sugar 2.0) is presented in Table 2. 
Table 2: The composition of Penipol

\begin{tabular}{lc}
\hline Constituent & $\begin{array}{c}\text { Level (dry weight } \\
\text { basis) }\end{array}$ \\
\hline Moisture & $29.68 \%$ \\
Crude protein & $3.58 \%$ \\
Crude fat & $20.78 \%$ \\
Crude fiber & $7.00 \%$ \\
Total ash & $0.83 \%$ \\
PH & 5.50 \\
Water activity & 0.80 \\
Total soluble solids(TSS) & $65^{\circ}$
\end{tabular}

Each value represents mean of three samples.

The composition is given as a percentage on

dry weight basis per $100 \mathrm{~g}$

Based on the proximate composition, the total energy value of Penipol was $391 \mathrm{kcal} / 100 \mathrm{~g}$. Since the product contains whole coconut kernel it is rich in dietary fiber and coconut protein. As Penipol contains about $20.78 \%$ fat, the addition of an antioxident into the mixture is important to avoid rancidity development. Penipol is a low acid product, but has $65^{\circ}$ brix (total soluble solids) and 0.8 water activity, indicating high osmotic pressure in the food.

\section{Pasteurization studies:}

Penipol jars stored without any heat treatment or after heating for $15 \mathrm{~min}$ in boiling water were spoiled within one month. Microbial analysis of samples heated for $30 \mathrm{~min}$. or longer showed no evidence of microbial growth. The low water activity $(0.8)$ of the product and $30 \mathrm{~min}$. heat processing appeared to be adequate to prevent microbial activity. Most bacteria do not grow below a water activity of 0.91 , whereas spoilage moulds can grow even at water activity as low as 0.80 . Osmophilic yeast has been reported to grow at water activity value of 0.61 (Jay 1996). However, most spoilage yeasts do not grow below a water activity of 0.88 . At any given temperature, the ability of microorganisms to grow is reduced as the water activity is lowered (Jay 1996). Therefore with, lower than conventional heat treatment in combination with a low water activity of 0.8 , it is possible to obtain a bottled Penipol with sterility up to required commercial standards.

\section{Shelf life study:}

Mean sensory scores for colour, appearance, taste, smell and overall acceptance of preserved Penipol samples drawn during the 12 months storage are shown in Table 3.0. 
Table 3: Median values of sensory scores at three months intervals over a period of one year storage

\begin{tabular}{|c|c|c|c|c|c|c|}
\hline $\begin{array}{l}\text { Sensory } \\
\text { attributes }\end{array}$ & $\begin{array}{l}\text { Fresh } \\
\text { sample }\end{array}$ & $\begin{array}{l}\text { Stored for } \\
3 \text { months }\end{array}$ & $\begin{array}{l}\text { Stored for } \\
6 \text { months }\end{array}$ & $\begin{array}{l}\text { Stored for } \\
9 \text { months }\end{array}$ & $\begin{array}{l}\text { Stored for } \\
12 \text { months }\end{array}$ & F ratio \\
\hline $\begin{array}{l}\text { Colour } \\
\text { Appearance } \\
\text { Taste } \\
\text { Smell } \\
\text { Overall } \\
\text { accept. }\end{array}$ & $\begin{array}{l}4.6+/-0.3 \\
4.7+/-0.3 \\
4.5+/-0.4 \\
4.3+/-0.3 \\
4.5+/-0.1\end{array}$ & $\begin{array}{l}4.6+/-0.1 \\
4.7+/-0.2 \\
4.5+/-0.3 \\
4.3+/-0.1 \\
4.5+/-0.3\end{array}$ & $\begin{array}{l}4.6+1-0.1 \\
4.7+/-0.1 \\
4.5+/-0.2 \\
4.3+/-0.4 \\
4.5+/-0.3\end{array}$ & $\begin{array}{l}4.6+1-0.3 \\
4.7+/-0.3 \\
4.4+/-0.5 \\
4.3+/-0.3 \\
4.5+/-0.4\end{array}$ & $\begin{array}{l}4.6+/-0.2 \\
4.7+/-0.2 \\
4.4+/-0.5 \\
4.3+/-0.1 \\
4.5+/-0.2\end{array}$ & $\begin{array}{l}0.250^{\text {NS }} \\
0.690^{\text {NS }} \\
0.607^{\text {NS }} \\
0.550^{\text {NS }} \\
0.250^{\text {NS }}\end{array}$ \\
\hline
\end{tabular}

It is evident that there is no significant difference in the sensory attributes tested between freshly prepared and preserved Penipol. This indicates bottled Penipol, pasteurized $30 \mathrm{~min}$ in a boiling water bath can be stored for at least 12 months without any deterioration or loss of consumer acceptance.

Hydrolysis of ester bonds in lipids mainly occur by enzyme activity and by heat with moisture, resulting in the liberation of free fatty acids (Fennema, 1995). Tocopherol is the antioxident vitamin widely used in the food industry to control the development of rancidity and it exerts its maximum effectiveness at relatively low concentrations, approximately $80 \mathrm{ppm}$. (Blockish 1998). Although coconut contains about $40 \%$ fat, changes in free fatty acids content of stored samples of the Penipol were insignificant $(p<0.05)$ during 12 months of storage, indicating vitamin $E(80 \mathrm{ppm})$ together with heat processing of bottled Penipol control the rancidity development during storage. Throughout the study period the free fatty acids level was maintained at $0.05+1-0.02$ (as \% of lauric acid).

\section{CONCLUSION}

Penipol can be preserved for at least twelve months by applying a simple bottling technique with $\mathbf{3 0} \mathrm{min}$. pasteurization in boiling water. 


\section{REFERENCES}

AOAC (1990) Official Methods of Analysis. Vol.2. Association of Official Analytical Chemists, Inc., Virginia.

Bockisch, M. (1998). Fats and Oils Handbook, second edition, AOCS Press, Champaign, Illinois.

Dhaliwal, M. and Hira, C.K.(2001). Effect of storage on physico-chemical and nutritional characteristics of carrot beet-root and carrot-black carrot juice, Journal of Food Science and Technology, Vol.38, No.4.

Fennema, O.R. (1995). Food Chemistry, third edition, Marcel Dekker Inc., USA

Jawahir, K. Badrie, N. Donawa, A. (2001). Effect of Blanching on Pickled Bitter Gourd (Momordica charantia), Journal of Food Science \& Technology, Vol.38, No.2.

Jay, J.M.J. (1996). Modern Food Microbiology, fifth edition, Chapman and Hall, Newyork.

Linda, B.M. (1979). Protein Enrichment of Coco Spread with Legume Flours, Philippine Journal of Coconut Studies, Vol. 1V.

Pearson, D. (1973). Laboratory Techniques in Food Analysis. Butterworth and Co. Ltd, England, Australia, Canada.

Semwal, A.D. Sharma, G.K. Patki, P.E. Padmashree, A. Arya, S S. (2001). Studies on Development and Storage Stability of Instant Vegetable Pulav Mix, Journal of Food Science and Technology, Vol.38, No.3. 